DOI https://doi.org/10.18551/rjoas.2017-06.09

\title{
THE AUTHORITY OF INDONESIA DEPOSIT INSURANCE CORPORATION IN HANDLING SYSTEMIC-AFFECTED BANK FAILURE AFTER THE CONSTITUTIONAL COURT'S DECISION NUMBER 53/PUU-XIII/2015
}

\author{
Septiana Fitri Rosi ${ }^{*}$, Santoso Budi, Sugiri Bambang, Magisters of Notary \\ University of Brawijaya, Malang, Indonesia \\ *E-mail: rossiseptiana@gmail.com
}

\begin{abstract}
One of the functions of Indonesia Deposit Insurance Corporation is actively maintaining banking system stability in accordance with its authority. The present research aims to analyze the authority of Indonesia Deposit Insurance Corporation in handling systemicaffected bank failure after the Constitutional Court's Decision Number 53/PUU-XIII/2015. This research used normative research approach, laws approach, and systematic interpretation. Besides using the primary legal materials, secondary legal materials were used as well to give enlightment that support primary legal materials. The result showed that the authority of Indonesia Deposit Insurance Corporation in handling systemic-affected bank failure after Constitutional Court's decision Number 53/PUU-XIII/2015 does not change. The decision of Constitutional Court only emphasizes the phrase of "selling all shares of bank" in Article 30 verse (1), Article 38 verse (1) andArticle 42 verse (1) of Laws Number 24 of 2004 regarding Indonesia Deposit Insurance Corporation is intended as share owned by Shareholder of Systemic-affected Bank Failure Controller that has made and submitted statement letter as mentioned in Article 9 letter a section 4 point (iii) of Indonesia Deposit Insurance Corporation's Laws. Thus, in the moment of selling shares of systemic-affected Bank Failure, Indonesia Deposit Insurance Corporation only has authority to sell shares from the Controller Shareholder, not including public shareholder from the Bank Failure.
\end{abstract}

\section{KEY WORDS}

Authority, Indonesia Deposit Insurance Corporation, systemic-affected, bank failure, bank failure handling, constitutional court.

In November 21 2008, Indonesia Deposit Insurance Corporation received submission of Century Bank, Tbk handling through Decision of Financial System Stability Committee that determines PT. Bank Century, Tbk as systemic-affected Bank Failure. In handling PT. Bank Century, Tbk, Indonesia Deposit Insurance Corporation obtains duty and function granted by Laws of the Republic of Indonesia Number 24 of 2004 regarding Indonesia Deposit Insurance Corporation which has been amended to Laws of the Republic of Indonesia Number 7 of 2009 ("Laws of Indonesia Deposit Insurance Corporation").

One of the functions of Indonesia Deposit Insurance Corporation, based on Article 4 of Indonesia Deposit Insurance Corporation's Laws, is actively maintaining banking system stability in accordance with its authority. Hence, in realizing the function, Indonesia Deposit Insurance Corporation has duties to: 1) Formulate and determine policy in order to actively maintain banking system stability, 2) Formulate, determine, and conduct settlement policy of unsystemic-affected Bank Failure, 3) Handle systemic-affected Bank Failure. ${ }^{1}$

In handling systemic-affected Bank Failure, based on the condition of Article 22 verse (1) letter b of Indonesia Deposit Insurance Corporation's Laws, it is set that the handling of systemic-affected Bank Failure is done by saving that involves or without involving the old shareholders. In handling PT. Bank Century, Tbk, Indonesia Deposit Insurance Corporation conducts saving actions without involving old shareholders because the shareholders do not

${ }^{1}$ Article 5 verse (2) of Indonesia Deposit Insurance Corporation's Laws 
fulfill the requirements of involvement in handling Bank Failure in accordance with the regulation in Article 33 verse (1) of Indonesia Deposit Insurance Corporation's Laws. ${ }^{2}$

After Indonesia Deposit Insurance Corporation takes over all rights and authorities of General Meeting of Shareholders, ownership, membership, and/or other concerns in Century Bank, Tbk $^{3}$, some saving actions, by Indonesia Deposit Insurance Corporation in handling period, are conducted by doing re-branding for Century Bank, Tbk by changing its name to be PT. Bank Mutiara, Tbk; arranging new business plan and Temporary Capital Participation ("PMS"). In handling PT. Bank Mutiara, Tbk, Indonesia Deposit Insurance Corporation pays handling cost with total as much Rp 8,011 Billion. All handling cost of Bank Failure paid by Indonesia Deposit Insurance Corporation becomes Temporary Capital Participation ("PMS") in Bank Failure ${ }^{4}$. Temporary Capital Participation of Indonesia Deposit Insurance Corporation towards PT. Bank Mutiara, Tbk is then converted to be in form of share in PT. Bank Mutiara, Tbk with the composition as follows: 1) Share of Series $A=801.184 .100 .000 .000$ $(99,9965 \%), 2)$ Share of Sharies B $=28.350 .177 .035(0,0035 \%)^{5}$.

What is meant by share of series $A$ is the share owned by Indonesia Deposit Insurance Corporation as the conversion outcome of Temporary Capital Participation, while share of series $B$ is the share owned by public society. As the continuation of systemic-affected Bank Failure handling, Indonesia Deposit Insurance Corporation, based on regulation in Article 42 verse (1) of Indonesia Deposit Insurance Corporation Law ${ }^{6}$, is obliged to sell all shares of Bank which is on the handling period. After passing some processes of share selling, the winning investor that will buy share of PT. Bank Mutiara, Tbk is chosen. The process of share selling to winning investor is done through 2 takeover phases: the first takeover is done on 99\% share with the selling price as much Rp4.411.111.111 in November 20, 2014, and the remaining $1 \%$ share consists of Indonesia Deposit Insurance Corporation's share and $0,0035 \%$ of society's share with the selling price as much Rp44.399.018 in which the takeover to an Indonesia legal entity will be conducted after fulfilling certain conditions. ${ }^{7}$ In the phase of Mutiara Bank's share selling, Indonesia Deposit Insurance Corporation faces problems related to the arrangement in Article 60 of Limited Liability Company Law when selling $0,004 \%$ share owned by society. Arrangement in Article 60 of Limited Liability Company Law ${ }^{8}$ mainly mentions that the share ownership also gives material rights to its owner. Thus, the share owners also have rights to get protection over their ownership. According to Capital Market Authority ${ }^{9}$, if Indonesia Deposit Insurance Corporation conducts the remaining share selling as much $0,00035 \%$ owned by public shareholders, then the takeover by state occurs through Indonesia Deposit Insurance Corporation without concerning on principles of humanities, justice, expediency, certainty, transparancy, agreement, participation, welfare, sustainability, and harmony and those aspects that also contradict with Article 28H verse (4) of Constitution of the Republic of Indonesia 1945.

In April 6, 2015, Indonesia Deposit Insurance Corporation supplicatedjudicial reviewto Constitutional Court on articles in Indonesia Deposit Insurance Corporation's Law that regulate share selling of Bank which are Article 30 verse (1), Article 38 verse (1) andArticle 42 verse (1). Those articles, according to Indonesia Deposit Insurance Corporation, are considered not giving legal certainty in the process of share selling which is the authority of Indonesia Deposit Insurance Corporation. In the articles regarding to selling, it is mentioned that Indonesia Deposit Insurance Corporation is obliged to sell the share of the saved bank or bank in handling. The "all bank share" phrase here invites different interpretation on its

\footnotetext{
${ }^{2}$ Annual Reportof Indonesia Deposit Insurance Corporation in 2008, page 56.

${ }^{3}$ Announcement of Indonesia Deposit Insurance Corporation Number:: PENG.003/KE/XI/2009 regarding Handling of PT. Bank Century, Tbk, published on website of Indonesia Deposit Insurance Corporation: www.Ips.go.id in November 30, 2009.

${ }^{4}$ Article 37 verse (2) of Indonesia Deposit Insurance Corporation's Laws

${ }^{5}$ Decision of Constitutional Court:Number 53/PUU-XIII/2015,pagel 6

${ }^{6}$ Article 42 verse (1) : Indonesia Deposit Insurance Corporation is obliged to sell all handled bank's shares maximum 3 (three) years since the beginning of Bank Failure's handling as mentioned in Article 39.

${ }^{7}$ Annual Reportof Indonesia Deposit Insurance Corporation of 2014, page 23.

${ }^{8}$ Article 60 verse (1) of Limited Liability Company's Laws states : "Materials over shares as moving objects grant material rights to its owner. The right can be maintained to everyone".

${ }^{9}$ As cited from expert witness' statement, Sarjito, SE, SH, MBA Commisioner Deputy of Capital Market Supervisor I of Financial Services Authority in Constitutional Court's Decision of the Republic of Indonesia Number 53/PUU-XIII/2015.
} 
meaning, which is whether the share selling of all bank share is only owned by Indonesia Deposit Insurance Corporation or all bank share is owned by both Indonesia Deposit Insurance Corporation and society, including public society that buys shares in Capital Market.Moreover, in the enlightenment of those articles, it does not attach meaning explanation of "all bank share". Concretely, according to Indonesia Deposit Insurance Corporation, it has caused legal uncertainty. Then, in September 7, 2016, Constitutional Court issued a decision regarding judicial review supplicated by Indonesia Deposit Insurance Corporationthrough Decision of Constitutional Court Number 53/PUU-XIII/2015.

By this Constitutional Court's decision, the writer will analyze further about the authority of Indonesia Deposit Insurance Corporation in handling systemic-affected Bank Failure after the decision of Constitutional Court.

\section{METHODS OF RESEARCH}

The present research utilizes judicial normative research method with laws approach, (McConville, 2007; Van Hoecke, 2011).The laws used as its legal materials are Decision of Constitutional Court Number 53/PUU-XIII/2015, Laws Number 24 of 2004 regarding Indonesia Deposit Insurance Corporation, Laws Number 7 of 1992 regarding Banking which has been amended to be Laws Number 10 of 1998, Bank of Indonesia Laws, Laws Number 40 of 2007 regarding Limited Liability Company, Laws Number 9 of 2016 regarding Prevention and Handling of Financial System Crisis, and Regulation of Indonesia Deposit Insurance Corporation. Besides using the primary legal materials, secondary legal materials are used as well to give enlightenment that support primary legal materials in form of law books, journal articles, and related researches' results (Soekanto, 2011).The legal materials collected through literature study and internet are then analyzed using systematic interpretation until it leads to a conclusion.

\section{RESULTS OF STUDY}

Judicial Review of Indonesia Deposit Insurance Corporation. As the judicial reviewrequest supplicated by Indonesia Deposit Insurance Corporation, the Constitutional Court inSeptember 7, 2016, issued a Decision Number 53/PUU-XIII/2015 over a quolndonesia Deposit Insurance Corporation'sSupplication, which mainly states that it does not need new interpretation on article and/or verse which its constitutionality must be tested, so that on its injunction part, the Constitutional Court refuses Indonesia Deposit Insurance Corporation's Supplication, with considerations as follows:

That ownership right on material is one of human rights. Article 36 verse (2) and Article 37 verse (1) of Laws Number 39 of 1999 regarding Human Rights mainly regulate that revocation of ownership right on material for public concern is only allowed by repaying the loss logically and immediately, and its implementation is in accordance with the prevailing laws. The substance of Indonesia Deposit Insurance Corporation's Supplication has an essence that it has authority to sell all shares of Bank Failure which is in its handling, including selling shares of other parties bought in Capital Market. Since it is related to ownership takeover, then it must be referred to the prevailing laws.

That personal ownership right is under the protection of constitution. Personal ownership right is one of human rights protected by constitution which cannot be taken arbitrarily by anyone (vide Article $28 \mathrm{H}$ verse (4) of Constitution of the Republic of Indonesia 1945).Share ownership gives material rights to its owner and the right can be maintained towards everyone (vide Article 60 verse (1) of Limited Liability Company's Laws). The protection of material rights on share owned by holder is the tangible implementation of protection over the guaranteed assets (vide Article $28 \mathrm{G}$ verse (1) of Constitution of the Republic of Indonesia 1945). This means that the taking or the transfer of shareholder right over share owned by someone still must fulfill protection element to its owner, and it is not implemented in arbitrary way. 
That share ownership by shareholder of Liability Company is the part of capital participation forms. Capital participation in Limited Liability Company is conducted in the moment of establishment or through Liability Company's share selling when it has been established, directly or through Capital Market both selling in share general offering and selling in secondary market (buy in Stock Exchange or out of Stock Exchange). Article 53 verse (2) of Limited Liability Company's Laws regulates rights of shareholder from similar share clarification, both founder and shareholder that buy shares directly or through Capital Market, and gives rights to its owner to attend and express opinion in General Meeting of Shareholder (RUPS), receives dividend payment, and remaining wealth from liquidation and other rights, attached in some articles in Limited Liability Company's Laws.

Ownership is absolute because it can be limited as long as it is set in laws. Article $28 \mathrm{~J}$ verse (4) ofConstitution of the Republic of Indonesia 1945 regulating about assets takeover for public concern by state can be conducted as long as the principles of justice, expediency, certainty, transparancy, agreement, participation, welfare, sustainability, and harmony are still guaranteed and upheld for asset owner taken for public concern.

Compensation on Ownership Right Takeover. The takeover of investor ownership right which is directly manifested by government (for state's concern) through nationalization cannot be realized unless government gives compensation in which its total refers to market price. $^{10}$

Submission of ownership on asset. Submission of all rights owned by shareholder cannot be done without submission of shareholder as asset owner based on civil law. Statement Letter of Controller Shareholder ("PSP") relinquishes ownership right if bank turns to be Bank Failure and decided to be saved (vide inArticle 9 letter a section (4) point (iii) of Indonesia Deposit Insurance Corporation's Laws) has a meaning that when Indonesia Deposit Insurance Corporationencounters Bank Failure, automatically ownership right of Controller Stakeholder is dominated by Indonesia Deposit Insurance Corporation. Therefore, after it conducts Temporary Capital Participation, the shareholder of Bank Failure comprises of Indonesia Deposit Insurance Corporation and public shareholder.

Restraint of Controller Shareholder in Liability Company. Controller Shareholder has major restraint access towards Bank policy including being able to commit an action for concern in Article 3 verse (2) of Limited Liability Company's Laws ${ }^{11}$, so that it leads to a regulation in Article 9 letter a section(4) point (iii) of Indonesia Deposit Insurance Corporation's Laws that requires a statement letter revealing willingness to relinquish and submit all rights, ownerships, memberships, and/or others to Indonesia Deposit Insurance Corporationif Bank turns to be Bank Failure and it is decided to be saved in which it is more emphasized in the explanation of Article 43 of Indonesia Deposit Insurance Corporation'sLaws which states that ittakes over and runs all rights and authorities of shareholder, including authority of Liquidation process in General Meeting of Shareholder.

The meaning of phrase "all bank's share". Ownership of public share does not include meaning of phrase "all bank's share" inArticle 30 verse (1), Article 38 verse (1), andArticle 42 verse (1) of Indonesia Deposit Insurance CorporationLaws because of the explanation of Article 9 letter a section (4) point (iii) jo. only sets the readiness of Controller Shareholder to relinquish and submit their share ownership to Indonesia Deposit Insurance Corporation, while public shareholder is not included as a party that states readiness to relinquish and submit their share ownership to Indonesia Deposit Insurance Corporation. If the meaning of phrase "all bank's share" in those three articles are interpreted that $100 \%$ of bank share that is taken over and submit their share ownership to Indonesia Deposit Insurance Corporation, so itwill be the only one shareholder on the Bank Failure, while if it is interpreted as all shares including public share, so it is a forced takeover by state which contradicts with Article $28 \mathrm{G}$ verse (1) jo. Article 28H verse (4) of Constitution of the Republic of Indonesia 1945.

\footnotetext{
${ }^{10}$ Banking Actin 2009 in Paragraph 49, 50, 51

${ }^{11}$ is with the bad faith to utilize Liability Company for personal interest; involving in the act against the law conducted by Liability Company; unlawfully using wealth of Liability Company that causes its wealth insufficient to pay debt of Liability Company.
} 
Saving Cost Return. Return of saving cost from the saved bank share selling is not interpreted that the return with share selling is done by selling share of Bank Failure owned by public shareholder.

Constitutional Court views that the different interpretation on the meaning of phrase "all bank's share" as attached in regulation formula of Article 30 verse (1), Article 38 verse (1), and Article 42 verse (1) of Indonesia Deposit Insurance CorporationLaws, whether it covers all bank's share is only owned by Indonesia Deposit Insurance Corporation or all bank's share is owned by both Indonesia Deposit Insurance Corporation and society, including public society that buys shares in Capital Market, so that it does not need new interpretation on article and/or verse which its constitutionality must be tested.

\section{DISCUSSION OF RESULTS}

Definition of Bank Failure. Bank Failure, according toArticle 1 section 2 of Laws Number 10 of 1998 regarding Amendment on Laws Number 7 of 1992 regarding Banking (herein after referred as Laws of Banking) is "Business entity that collects fund from community in form of saving and distributes it to community in form of credit and or other forms in order to improve community life quality." According to O.P Simorangkir, Bank is one of business entities of financial institutions that aims to give credits and services. The lending is done either through personal capital or with funds trusted by third party or through emitting means of payment in form of demand deposit (Sembiring, 2012).

Failure of a bank is usually caused by problems in the bank itself. A bank is considered in problem if the bank faces difficulty that can endanger its business continuity which is the Bank's business condition is getting worse marked by the decline of Capital, Asset Quality, Management, Rentability, Liquidity, and Sensitivity on Market Risk and bank management which is not realized based on caution principles (Zaini, 2012).

These are definitions of Bank Failure based on the related provisions:

Based on Article 1 section 5 Bank of Indonesia's Regulation Number 10/31/PBI/2008 regarding Emergency Financing Facility for Conventional Bank, what is called as Bank Failure is the bank which faces financial difficulty in form of liquidity difficulty. Liquidity difficulty is difficulty of short-term financing experienced by bank caused by the incoming fund that is lower than the outcoming fund (mismatch). Itleads to negative demand balance, and/or solvency difficulty which is the capital difficulty experienced by bank so that it does not fulfill Minimum Capital Adequacy Requirement (KPMM), set by Bank of Indonesia, which endangers its business continuity.

Based on regulation of Article 1 section 7 of Indonesia Deposit Insurance Corporation's Laws, what is meant by Bank Failure is the bank that experiences financial difficulty and endangers its business continuity and it is stated that it cannot be fixed anymore by Banking Supervisory Agency (herein after referred as LPP) in accordance with its authority.

According to Zaini \& Febriansyah, (2014) as cited from book entitled withLegal Aspect and Indonesia Deposit Insurance Corporation Function, the meaning of Bank Failure is the bank which faces liquidity difficulty. Liquidity difficulty is difficulty of short-term financing because the predicted incoming and outcoming cashflow. This can make negative balance and solvency difficulty or capital, so that it cannot fulfill Minimum Capital Adequacy Requirement. From some definitions of Bank Failure aforemmentioned, it can be stated that Bank Failure is the bank which faces liquidity difficulty and it can endanger its business continuity as well as it cannot be fixed by Banking Supervisory Agency (LPP).

In Laws of Indonesia Deposit Insurance Corporation, Bank Failure is categorized into 2 (two) groups: systemic-affected Bank Failure and unsystemic-affected Bank Failure. The meaning of systemic-affected ${ }^{12}$, according to Krisna Wijaya, is if the failure of bank will give huge effects both on rush and on economy continuity (Wijaya, 2007).Then, the definition of systemic-affected Bank Failure, based on regulation of Article 1 of Indonesia Deposit Insurance Corporation'sLaws Number 5 of 2006 regarding Handling of Systemic-affected

\footnotetext{
${ }^{12}$ Before the prevailing of Prevention and Handling of Financial System Crisis's Laws.
} 
Bank Failure as amended to be Indonesia Deposit Insurance Corporation's Laws Number 3 of 2008,is Bank Failure considered giving systemic effect by Coordination Committee in which its handling is given to Indonesia Deposit Insurance Corporation.

Authority of Handling Bank Failure by Indonesia Deposit Insurance Corporation. Based on regulation set in Article 5 verse (2) of Indonesia Deposit Insurance Corporation's Laws, in actively participating in maintaining banking system stability in accordance with its authority, Indonesia Deposit Insurance Corporation has duties to ${ }^{13}$ :

Formulate, determine, and conduct policy of bank resolution of unsystemic-affected Bank Failure; and

Conduct handling of systemic-affected Bank Failure.

For unsystemic-affected Bank Failure, Indonesia Deposit Insurance Corporation may save or not save after Banking Supervisory Agent or Coordinating Committee submits its resolution to it ${ }^{14}$. Its decision to save a Bank Failure is based on saving cost calculation which covers capital increase until the bank fulfills condition of solvency level and liquidity level. ${ }^{15}$ Moreover, Indonesia Deposit Insurance Corporation'sLaws Number 4 of 2006 regarding Resolution of Unsystemic-Affected Bank Failure, which is amended to be Indonesia Deposit Insurance Corporation's Regulation Number 2 of2007, states that to save a Bank Failure, it must fulfill some conditions which are as follows: ${ }^{16}$

- The highest saving cost estimation is $60 \%$ from the unsaved cost estimation;

- Bank still has good business prospect;

- There is a statement from Bank in General Meeting of Shareholder; and

- Bank submits several documents to Indonesia Deposit Insurance Corporation.

While for unsystemic-affected Bank Failure, the handling will be conducted after there is a submission from Coordinating Committee to Indonesia Deposit Insurance Corporation ${ }^{17}$. The implementation of systemic-affected Bank Failure resolution is named handling term to distinguish from settlement terms used in resolution of unsystemic-affected Bank Failure, (Prasetya, 2016).Bank Failure's handling, according to regulation set in Article 1 section 7 of Indonesia Deposit Insurance Corporation's Laws Number 1 of 2014 regarding Share Selling of the Saved Bank Failure, is a set of actions of Indonesia Deposit Insurance Corporation to save systemic-affected Bank Failure mandated by Coordinating Committee to it with or without involving old shareholder.

In Indonesia Deposit Insurance Corporation's Laws, it is mentioned that systemicaffected Bank Failure is conducted by Indonesia Deposit Insurance Corporation in two ways: by involving old shareholder (open bank assistance) or without involving shareholder. ${ }^{18}$ In terms of Bank Failure's handling by involving old shareholder, it can be done if the following conditions are fulfilled: ${ }^{19}$

Old shareholder of Systemic-affected Bank Failure has deposit capital at least $20 \%$ (twenty percents) from handling cost estimation;

There is a statement of Bank in General Meeting of Shareholder which at least contains willingness to:

- Grant rights and authorities of General Meeting of Shareholder to Indonesia Deposit Insurance Corporation;

- Submit bank management to Indonesia Deposit Insurance Corporation; and

- Not prosecute Indonesia Deposit Insurance Corporation or other parties chosen by it in terms of unsuccesful handling process, as long as Indonesia Deposit Insurance Corporation or the parties chosen by it runs its duties based on prevailing regulations started from date of Bank Failure's handling submission by Coordinating Committee to Indonesia Deposit Insurance Corporation;

\footnotetext{
${ }^{13}$ Article 5 verse (2) of Indonesia Deposit Insurance Corporation's Laws

${ }^{14}$ Article 21 verse (2) of Indonesia Deposit Insurance Corporation's Laws

${ }^{15}$ Article 23 verse (1) of Indonesia Deposit Insurance Corporation's Laws

${ }^{16}$ Article 10 of Indonesia Deposit Insurance Corporation's Unsystemic-affected Bank

${ }^{17}$ Article 21 verse (3) of Indonesia Deposit Insurance Corporation's Laws

${ }^{18}$ Article 32 of of Indonesia Deposit Insurance Corporation's Laws jo Article 4 of Indonesia Deposit Insurance Corporation's

Systemic Bank

${ }^{19}$ Article 5 of Indonesia Deposit Insurance Corporation's Systemic Bank
} 
Bank submits some documents to Indonesia Deposit Insurance Corporation which cover:

- Use of Funding Facility from Bank of Indonesia;

- Financial Data of Debitor's Customers;

- Capital structure and list of shareholders in last 3 years; and

- Other information regarding to asset, obligation, and capital of bank required by Indonesia Deposit Insurance Corporation.

Requirement to capital deposit at least 20\% (twenty percents) by Bank Shareholder whose shares are not exchanged in Capital Market, it is obliged to be fulfilled in 15 working days after Indonesia Deposit Insurance Corporation receives transfer of systemic-affected Bank Failure from Coordinating Committee, while for Bank whose shares are exchanged in Capital Market, it is obliged to deposit capital in 35 working days after Indonesia Deposit Insurance Corporation receives systemic-affected Bank Failure from Coordinating Committee. ${ }^{20}$ Furthermore, if all requirements mentioned above have been fulfilled, then Indonesia Deposit Insurance Corporation will decide to conduct handling by involving old shareholder. Decision to conduct handling by involving old shareholder is done by it not later than 3 working days after the due date of requirement fulfillment to capital deposit by Old Shareholder ${ }^{21}$.

Then, started from Indonesia Deposit Insurance Corporation that conducts handling by involving Shareholder, then it results: ${ }^{22}$

- Shareholder and committee of Bank relinquish and grant all rights, ownerships, memberships, and/or other concerns to Indonesia Deposit Insurance Corporation; and

- Shareholder and committee of bank do not prosecute Indonesia Deposit Insurance Corporationor parties chosen by itin the process of unsuccesful handling, as long as Indonesia Deposit Insurance Corporationor parties chosen by it runs its function in accordance with regulations.

After General Meeting of Shareholder grants its rights and authorities to Indonesia Deposit Insurance Corporation, then some actions that can be done by it, based on regulation in Article 26 of Indonesia Deposit Insurance Corporation'sLaws, are Dominating, Managing, and Committing action of Ownership on asset or the things that become rights and/or obligation of bank, and executing temporary capital participation, and shifting bank management to other parties.

In the process of Bank Failure's handling in Indonesia, it recognizes some resolution methods. However, before choosing method that will be employed for handling process, besides concerning on social-economy condition of Indonesia in the present and in the future, there are 2(two) main principles that can be used to choose the method which are (Prasetya, 2016):

- Least Cost Resolution Principle obliges resolution authority to choose what option that has the lowest cost from all available options. In this principle, evaluation and calculation of all cost from alternative resolution are done by referring to net present value basis dan a realistic discount rate (Wong-Keun Yang, Sun Eae Chun, Martha C. Duncan,2001)..

- Lower cost resolution obliges to choose one of resolution options which has the lowest cost compared to other options if bank's business license is revoked, so that it must pay insurance claim and run bank's liquidation process.

After implementing those two principles above, then Indonesia Deposit Insurance Corporation must choose resolution method that will be used to handle bank. These are the resolution methods which commonly prevail in some countries:

Reimbursement (payout) of insured depositors. Reimbursement method or payout method is commonly used when a Bank Failure's business license is revoked (William Su,

\footnotetext{
${ }^{20}$ Article 7 of Indonesia Deposit Insurance Corporation's Systemic Bank

${ }^{21}$ Article 9 verse (2) of Indonesia Deposit Insurance Corporation's Systemic Bank P

${ }^{22}$ Article 11 of Indonesia Deposit Insurance Corporation's Systemic Bank
} 
2006).In this reimbursement option, there is an obligation of resoluton option to pay customers' saving claim of Bank Failure which its business license is revoked. Then, payment cost of customers' saving by the resolution authority will be changed with results of assets selling from the Bank Failure or it is more known as Banking Liquidation.

Purchase and Assumption (P\&A). P\&A method, according to General Guidance For Resolution of Bank Failuresfrom International Association Deposit Insurance (IADI, 2006), is defined as the takeover process of partial or all assets from Bank Failure as well as its obligation by Healthy Bank. Afterwards, resolution authority will give incentive to Healthy Bank that takes over assets and obligations of the Bank Failure. Then, the business license of Bank Failure, which its assets and obligations are taken over partly or entirely, will be revoked.

Bridge Bank. In the method of Bridge Bank, resolution authority will establish a bank or called Intermediary Bank to accommodate and manage partial asset or all asset temporarily and obligation of Bank Failure. Moreover, this Intermediary Bank will be sold to investor if its resolution process is accomplished. According to Hari Prasetya, this Bridge Bank method is the variation of $P \& A$ option. The difference is the type of Bank that will manage asset and obligation of Bank Failure. For P\&A, the bank that will manage partial asset or all asset of Bank Failure is healthy bank that indeed has operated, while in Bridge Bank, the bank that will manage it is a temporarily new-established bank by Resolution Authority.

In the practice of Bridge Bank in some countries in the world, when resolution period has ended, the thing sold to investor is not Intermediary Bank, but it is only portfolio of its asset and obligation. Hence, this bridge bank practice is similar to establishment of asset Management Company.

Open Bank Assistance. Cited fromGeneral Guidance For Resolution of Bank Failures IADI, Open Bank Assistance ("OBA") is a resolution method in which a Bank Failure gets help from Resolution Authority in form of capital increase, deposit giving, or merger and acquisition. In OBA, resolution authority can place management team to manage bank. This OBA is frequently called bail-out.In OBA, it is commonly equipped with process of bank restructurization and also other improvement processes. Generally, this method is chosen to systemic-affected Bank Failure on banking system stability,(Prasetya, 2016)or if failure of a bank causes serious threat for finance stability and economy (William Su, 2006). Even if it is still used in some countries in the world, this OBA method is started to be left. For example, in America in 2010, The Dodd-Frank Wallstreet Reform and Consumer Protection Act ${ }^{23}$ revokes this OBA option (FDIC, 2014).

In Indonesia's banking itself, handling process of Bank Failure which is the authority of Indonesia Deposit Insurance Corporation, based on Indonesia Deposit Insurance Corporation's Laws, uses two resolution methods: Reimbursement and Banking Liquidation and Open Bank Assistancewhich are conducted with Temporary Capital Participation or Merger and Consolidation. However, after Indonesia Deposit Insurance Corporation's Laws is set in April 15 2016, it obtains two additional methods that can be used: Purchase and Assumption (P\&A) andBridge Bank. The addition of two methods is set in Article 22 verse (1) of Prevention and Handling of Financial System Crisis Laws. ${ }^{24}$

Judicial Review Supplication by Indonesia Deposit Insurance Corporation. Judicial review Supplication is requested by Indonesia Deposit Insurance Corporation when it conducts systemic-affected Bank Failure's handling, PT. Bank Century, Tbk, which then it is changed to be PT. Bank Mutiara, Tbk. In the process of Mutiara Bank's handling, the resolution method used by Indonesia Deposit Insurance Corporation is OBA orBail-out. One

\footnotetext{
${ }^{23}$ The Dodd-Frank Wallstreet Reform and Consumer Protection Act is a law that sets about the newest America's financial regulation and legalized in July 10, 2010. The arrangement of this law aims to prevent causes of financial crisis in United States of Amerika some years ago. The law significantly influences authority of FDIC in its role as Banking Supervisor, Receiver, and an agency that runs function of Customer's Deposit Insurance as well as causes organizational srtucture change of FDIC.

${ }^{24}$ Article 22 verse (1) of Prevention and Handling of Financial System Crisis's Laws mentions as follows: "Solvency problems

handling of Systemic Bank by Indonesia Deposit Insurance Corporation is implemented by these ways:

a. $\quad$ Transferring a part of or all of assets and/or obligation of Systemic Bank to Recipient Bank;

b. Transferring a part of or all of assets and/or obligation of Systemic Bank to Intermediary Bank; or

c. $\quad$ Conducting Bank handling as in accordance with Laws regarding Indonesia Deposit Insurance Corporation."
} 
of actions done by Indonesia Deposit Insurance Corporationwith OBA method is operating Temporary Capital Participation ${ }^{25}$ ("PMS"). Temporary Capital Participation, according to Article 1 section 11 of Indonesia Deposit Insurance Corporation, emphasizes that share selling will be counted as saving cost toward a bank and it is temporary because Indonesia Deposit Insurance Corporation is obliged to sell shares of Bank Failure in certain period with optimum return level. ${ }^{26}$ Share selling, or it is commonly known divestment, is the selling of securitiesand/or government ownership either partly or entirely to other parties(Salim, 2013)

Based on provision in Indonesia Deposit Insurance Corporation's Law of Share Selling, bank's share selling can be processed in two methods: strategic sale and/or other methods which do not contradict with prevailing legal provisions and laws. ${ }^{27}$ This share selling process is also realized openly and transparantly by keep considering the optimum return level for Indonesia Deposit Insurance Corporation. ${ }^{28}$

Share selling processes of Bank Failure based on provision in Indonesia Deposit Insurance Corporation's Laws Number 1 of 2014 regarding Share Selling of the Saved Bank Failure Process ("Indonesia Deposit Insurance Corporation'sLaw of Share Selling") are as follows:

Investor's Interest Delivery. Share selling process of Bank Failure is initiated with the interest delivery by investor to Indonesia Deposit Insurance Corporation. The investor candidate delivers letter containing statement that the candidate fulfills the desired requirements and other requirements set by Indonesia Deposit Insurance Corporation; ${ }^{29}$ and has commitment and strong financial independency to fulfill all payment obligation on transaction of Share Selling of the Saved Bank punctually.

Investor Candidate Selection. Selection process of Indonesia Deposit Insurance Corporation is done by giving assessment to investor candidate that has fulfilled requirement as set in Article 7 verse (1) of Indonesia Deposit Insurance Corporation's Laws about Share Selling. Then, from the assessment, it will determine the winning investor candidate and then propose to Financial Services Authority to have fit and feasibility test towards the winning investor candidate.

After accomplishing the tests, Indonesia Deposit Insurance Corporation will determine the winning investor that deserves to buy shares from the Bank Failure.

Payment and Share Transfer. The last phase of share selling processes is payment and share transfer process. The process of payment on share selling transaction of the saved bank can be done by investor gradually or abruptly. ${ }^{30}$ Then, share ownership of the saved bank sold by Indonesia Deposit Insurance Corporation is transferred to investor after all share selling price is paid. The deliverance of the saved bank is declared to end after share ownership of the saved bank, sold by Indonesia Deposit Insurance Corporation, is transferred by investor. ${ }^{31}$

In the share sellling of PT.Bank Mutiara, Tbk by Indonesia Deposit Insurance Corporation in September 12, 2014, Indonesia Deposit Insurance Corporation and J Trust have signed Agreement of Conditional Share Purchase and Selling in which its content agrees that the sold object is all shares of PT. Bank Mutiara, Tbk. Moreover, its share is owned by Indonesia Deposit Insurance Corporation as much $99,9965 \%$ and the share is owned by society as much $0,0035 \%{ }^{32}$. The first transfer conducted over $99 \%$ share in November 20,2014, and the remaining $1 \%$ share which comprises of $0.996 \%$ share of Indonesia Deposit Insurance Corporation and $0,004 \%$ share of society will be processed to a Legal Entity of Indonesia if it has fulfilled certain conditions. ${ }^{33}$

\footnotetext{
${ }^{25}$ Article 26 of Indonesia Deposit Insurance Corporation's Laws

${ }^{26}$ Article 42 of Indonesia Deposit Insurance Corporation's Laws

${ }^{27}$ Article 3 Verse (1) of Indonesia Deposit Insurance Corporation's Laws about Share Selling

${ }^{28}$ Article 4 verse (2) of Indonesia Deposit Insurance Corporation's Laws about Share Selling

${ }^{29}$ Article 7 verse (1) of Indonesia Deposit Insurance Corporation's Laws about Share Selling

${ }^{30}$ Article 9 of Indonesia Deposit Insurance Corporation's Laws about Share Selling

${ }^{31}$ Article 13 of Indonesia Deposit Insurance Corporation's Laws about Share Selling

${ }^{32}$ Putusan Mahkamah Konstitusi Nomor 53/PUU-XIII/2015, hal. 39

${ }^{33}$ Annual Report Lembaga Penjamin Simpanan Tahun 2014, hal 23.
} 
At that time, judicial reviews supplicated by Indonesia Deposit Insurance Corporation since at the moment of selling $0,004 \%$ share of society, there are issues from related capital market authority set in Article 60 of Limited Liability Company's Laws ${ }^{34}$ which the main point is that share ownership also grants material rights to its owner. Thus, share owner also deserves to obtain protection on his ownership. According to Capital Market Authority ${ }^{35}$, if Indonesia Deposit Insurance Corporation conducts selling of remaining 0,0035\% share owned by public shareholder, then takeover is executed by state through Indonesia Deposit Insurance Corporation without paying attention on principles of humanities, justice, expediency, transparancy, agreement, participation, welfare, sustainability, harmony, and other elements that contradict with Article $28 \mathrm{H}$ verse (4) of Constitution of the Republic of Indonesia 1945.

Then, in April 6 2015, Indonesia Deposit Insurance Corporation supplicated judicial review to Constitutional Court. Judicial Review itself is a process of legislation testing.According to Soebechi (2016), Indonesia Law System through judicial review mechanism, the suppliant proposes an objection regarding:

- Law Material that is considered contradicting with Constitution, then objection can be supplicated to Constitutional Court.

- Law Material under law which is considered contradicting with higher laws and provision, then objection can be supplicated to Supreme Court.

- Decision, action, and/or discretion of officials or state administrative bodies can propose an objection to Administrative Court.

What is meant by suppliant based onArticle 51 verse (1) Laws Number 24 of 2003regarding Constitutional Court ("Laws of Constitutional Court") jo. Article 3 of Constitutional Court's Regulation Number No. 6/PMK/2005 (PMK 6/2005") is "Suppliantis the party considering his constitutional right and/or obligation harmed by the prevailing laws, which are as follows:

- Individual Citizen of Indonesia;

- Unity of Customary Law's society as long as it is alive and it is in accordance with society growth and principle of Unity of the Republic of Indonesia as set in Laws;

- Public or private legal entity; or

- State Institution.

Then, what is meant by constitutional right, according to explanation of Article 51 verse (1) of Constitutional Court Law, is "rights set in Constitution of the Republic of Indonesia 1945, while what is meant by Individual is included into group of people who have same interest."

By referring to the provisions above, according to Prof. Dr. Jimly Asshiddiqie (Asshiddiqie, 2010), it can be known that every suppliant must:

- Being one of the four groups of legal subjects as mentioned in Article 51 verse (1) of Constitutional Court Law jo. PMK 6/2005

- That legal subject indeed has right or obligation as set in Constitution of the Republic of Indonesia 1945;

- That right or obligation of the suppliant has been harmed or disobeyed by the prevailing laws or part of the problematized laws;

- That harm is indeed proven as having causality or causal verband by the prevailing laws;

- That if the supplication is granted, and then the constitutional harm of the suppliant can be restored by cancelling the laws.

As one of legal subjects, based on Article 51 verse (1) of Constitutional Court's Laws jo. Constitutional Court's Regulation 5/2005, in principal case of judicial review supplicated

\footnotetext{
${ }^{34}$ Article 60 verse (1) UUPT menyatakan : "Kebendaan atas saham sebagai benda bergerak memberikan hak kebendaan kepada pemiliknya. Hak tersebut dapat dipertahankan terhadap setiap orang".

${ }^{35}$ Sebagaimana dikutip dari pernyataan saksi ahli Bapak Sarjito, SE, SH, MBA Deputi Komisioner Pengawas Pasar Modal I OJK dalam Putusan Mahkamah Konstitusi Republik Indonesia Nomor 53/PUU-XIII/2015.
} 
by Indonesia Deposit Insurance Corporation, supplication of judicial review is based on these following elements:

Article 30 verse $(1)^{36}$, Article 38 verse $(1)^{37}$, and Article 42 verse $(1)^{38}$ of Indonesia Deposit Insurance Corporation'sLaws do not grant legal certainty. Itargues that those aforementioned articles do not attach explanation of "all bank share". This concretely causes legal uncertainty in selling process of Mutiara Bank handled by it. Furthermore, according to Indonesia Deposit Insurance Corporation, it deserves to obtain legal certainty as stated in Article 28D verse (1) of Second Amendment of Constitution of the Republic of Indonesia $1945^{39}$.

There are different interpretations regarding to the meaning of "all bank share" phrase as stated in the provisions of Article 30 verse (1), Article 38 verse (1) andArticle 42 verse (1) of Indonesia Deposit Insurance Corporation'sLaws: whether it covers all shares both share of Indonesia Deposit Insurance Corporationand society including public society who buys shares in capital market.

The pros and contras of all shares selling of the saved Bank or the handled Bank.

The pros and cons divide opinions into two groups: first, the pro group stating that Indonesia Deposit Insurance Corporation has an authority to sell all shares by consideration that if the share selling process cannot be processed, then it can be understood that Indonesia Deposit Insurance Corporation does not obey its own provisions. On the other hand, this pro group also believes that norms formulation in Indonesia Deposit Insurance Corporation's Laws has been mentioned explicitly that it is obliged to sell all shares without exception to society's shares both in norms formulation and in the explanation of the laws. Then, in the arrangement of Indonesia Deposit Insurance Corporation's Laws, there is an obligation for it to conduct bank's share selling with optimum return level. In here, it can be known that Indonesia Deposit Insurance Corporation is required to do some actions in share selling in order to gain optimum results including in the essence of selling all shares of Bank Failure that involves society's shares. It is automatically interpreted as public authority of a state institution in which if Indonesia Deposit Insurance Corporation does not sell bank's shares, then it can be considered that it harms state finances.

Second, the cons group asserts that Indonesia Deposit Insurance Corporation does not deserve to sell society's shares with consideration that selling society's shares is contradicting with constitution mentioned inArticle $28 \mathrm{H}$ verse (4) of Constitution of the Republic of Indonesia $1945 .{ }^{40}$ Besides, there is an opinion that even if Indonesia Deposit Insurance Corporation has done Temporary Capital Participation to Bank Failure, it does not eliminate society's share ownership since society does not gain their shares through the process against the law, so that there is no any fundamental reason to eliminate their rights over their shares. However, the fact shows that Temporary Capital Participation makes percentage of society's share value lower.

There is a probability that potential lawsuit may happen toward Indonesia Deposit Insurance Corporationfrom the society shareholder who has share of Mutiara Bank as much $0.0035 \%$.

Authority of Indonesia Deposit Insurance Corporation after the Constitutional Court's Decision. From decisions and considerations of Constitutional Court as mentioned previously, based on authority, there is not any change of Indonesia Deposit Insurance Corporation'sauthority in handling systemic-affected Bank Failure. However, there are some things that become implications of Constitutional Court decision as seen from some sides which are as follows:

\footnotetext{
36 "Indonesia Deposit Insurance Corporation is obliged to sell all saved bank's shares in the period of maximum 2 (two) years since the submission as mentioned in Article 25".

37 "Indonesia Deposit Insurance Corporation is obliged to sell all handled bank's shares maximum 3 (three) years since submission as mentioned in Article 34 letter a".

38 "Indonesia Deposit Insurance Corporation is obliged to sell all handled bank's shares maximum 3 (three) years since the beginning of Bank Failure's handling as set in Article 39".

39 "Every person has a right on recognition, insurance, protection, and fair legal certainty as well as equal treatment before the law".

40 "Every person deserves to have an individual right and the right cannot be taken arbitrarily by anyone"
} 
Related to the interpretation of all Shares Selling in Article 30 verse (1), Article 38 verse (1) and Article 42 verse (1) of Indonesia Deposit Insurance Corporation's Laws. Since decision of Constitutional Court does not give new interpretation on "selling all bank's share" phrase in those aforementioned articles, so in conducting share selling of the handled Bank Failure, Indonesia Deposit Insurance Corporation only has an authority to sell share from Controller Shareholder (PSP) on Bank Failure. Besides, public shareholder is not included as a party whose share can be sold by Indonesia Deposit Insurance Corporation.

Related to statement letter of Shareholder. In Article 9 of Indonesia Deposit Insurance Corporation's Laws ${ }^{41}$, it is granted an authority to ask for a statement letter from Director, Commissioner Board, and Bank Shareholder when bank becomes the participant of Indonesia Deposit Insurance Corporation. Hence, when bank is declared as a Bank Failure, then it directly can sell shares from Controller Shareholder. However, the problem that occurs here is how if Controller Shareholder of Bank Failure does not make any statement letter? This absolutely implies that Indonesia Deposit Insurance Corporation cannot sell shares from Controller Shareholder since there is no commitment of relinqushing and submitting to Indonesia Deposit Insurance Corporation if bank turns to be Bank Failure and it is decided to be saved by it. Then, the second problem is that it does not close a possibility that composition of shareholder in a bank is the involvement of other shareholder in which Financial Service Authority (OJK) does not include it to qualification of both Controller Shareholder and public shareholder. The shareholder mentioned is not stated clearly in Decision of Constitutional Court Number 53/PUU/XIII/2015. This qualification of shareholder does not buy share from exchange, but its obtaining process can be started from the Closed Company which then turns to be go public. This shareholder absolutely must be viewed as having same position as public shareholder which is both are not included as parties that must state readiness to relinquish and submit their share rights and ownership to Indonesia Deposit Insurance Corporation if bank turns to be Bank Failure and it is decided to be saved or liquidated.

Related to obligation of Indonesia Deposit Insurance Corporation to sell shares with the optimum return level in accordance with regulation of Article 42 verse (3) of Indonesia Deposit Insurance Corporation's Laws. In Indonesia Deposit Insurance Corporation Laws in Article 42 verse (1), it is obliged to sell the handled bank's shares by concerning on optimum return level ${ }^{42}$. By limitation of Indonesia Deposit Insurance Corporation's obligation as explained in section 1, then there is risk potency that it cannot fulfill regulation of optimum return as set in Article 42 verse (2) of Indonesia Deposit Insurance Corporation's Laws. Therefore, it can not be blamed if regulation in Article 42 verse (2) of Indonesia Deposit Insurance Corporation's Laws is not fulfilled.

By comprehending explanation of some implications of Constitutional Court Decision Number 53/PUU-XIII/2015 above, the decision of Constitutional Court viewed from authority, can be stated that it reduces authority of Indonesia Deposit Insurance Corporation in handling systemic-affected Bank Failure, especially in the moment of Indonesia Deposit Insurance Corporation that must conduct share selling process of Bank Failure.

\section{CONCLUSION}

Based on the explication aforementioned, it can be concluded that:

\footnotetext{
${ }^{41}$ Article 9 letter a section 4of Indonesia Deposit Insurance Corporation's Laws states: "As the participant of insurance as mentioned in Article 8, every Bank is obliged to:

a. Submit documents as follows:

...4)Statement letter as set in Article 9 contains statements from Shareholder:

a) Being ready to relinquish and submit all rights, ownership, membership, and/or concern to Indonesia Deposit Insurance Corporationif bank turns to be Bank Failure and it is decided to be saved or liquidated;

b) Being ready personally to be responsible for any negligence and/or action against the law that harms or endangers bank's business continuity; and

c) Committing and being ready to obey all provisions as determined in Indonesia Deposit Insurance Corporation's Regulation...

${ }^{42}$ Article 42 verse (3) states that the optimum return level as mentioned in verse (2) is at least as much of all temporary capital placement incurred by Indonesia Deposit Insurance Corporation.
} 
By the decision of Constitutional Court Number 53/PUU-XIII/2015, the authority of Indonesia Deposit Insurance Corporation to handle systemic-affected Bank Failure does not change. However, one of the processes of the Bank Failure's handling, which is the process of share selling, Indonesia Deposit Insurance Corporation only has an authority to sell shares of Bank Failure's Controller Shareholder that has made and submitted statement letter as mentioned in Article 9 letter a section 4 point (iii) of Indonesia Deposit Insurance Corporation'sLaws.

There is a risk possibly faced by Indonesia Deposit Insurance Corporationin handling systemic-affected Bank Failure which is the unfulfillment of optimum return level for Indonesia Deposit Insurance Corporation on costs incurred by it in handling the Bank.

\section{REFERENCES}

1. Asshiddiqie, J. (2010). Hukum Acara Pengujian Undang-Undang. Jakarta: Sinar Grafika.

2. FDIC. (2014). Resolutions Handbook.

3. Indonesia Deposit Insurance Corporation. (2014). Energi yang Kuat untuk Langkah Selanjutnya: Laporan Tahunan.

4. International Association of Deposit Insurers (IADI). (2006). Guidance on the Resolution of Bank Failures.

5. McConville, M. (2007). Research Methods for Law. Edinburg University Press.

6. Prasetya, H. (2016). Mengupas Peran (Penting) INDONESIA DEPOSIT INSURANCE CORPORATION dalam Sistem Perbankan. Depok: Indie Publishing.

7. Salim, H. S., \& Septiana, E. (2012). Hukum Divestasi di Indonesia (Pasca Putusan MK RI Nomor 2/SKLN-X/2012).

8. Sembiring, S. (2012). Hukum Perbankan Edisi Revisi. Bandung: Mandar Maju.

9. Soebechi, I. (2016). hak Uji Materiil. Jakarta: Sinar Grafika.

10. Soekanto, S., \& Mamudji, S. (2011). Penelitian Hukum Normatif. Jakarta: Rajawali Press.

11. Su, W. (2006). General Guidance for the Resolution of Bank Failures. Journal of Banking Regulation, 8(1), 85-112.

12. Van Hoecke, M. (2011). Methodologies of Legal Research: Which Kind of Method for What Kind of Discipline? Bloomsbury Publishing.

13. Wijaya, K. (2007). Penanganan Bank Gagal, Jakarta:INDONESIA DEPOSIT INSURANCE CORPORATION. Retrieved from Indonesia Deposit Insurance Corporation: http://Indonesia Deposit Insurance Corporation

14. Yang, W.-K., Chun, S. E., \& Duncan, M. C. (2001). Failure Resolution Methods,Cost, and Policy Implications: Experiences in the U.S and Korea. Retrieved from http://www.kmfa.or.kr/paper/sympo/2001/workshop01_03.pdf

15. Zaini, Z. D. (2012). Independensi Bank Indonesia dan Penyelesaian Bank Bermasalah. Bandung: Keni Media.

16. Zaini, Z. D., \& Febriansyah, S. (2014). Aspek Hukum dan Fungsi Lembaga Penjamin Simpanan. Bandung: Keni Media.

17. Law Number 24 Year 2004 regarding to Deposit Insurance Corporation.

18. Law Number 40 Year 2007 regarding to Limited Liability Company.

19. Law Number 9 Year 2016 on the Prevention and Handling of Financial System Crisis

20. Law Number 17 Year 2003 regarding to State Finances.

21. Law Number 24 Year 2003 regarding to the Constitutional Court

22. Law Number 8 of 1995 concerning the Capital Market.

23. Act Number 7 of 1992 concerning Banking as amended by Act Number 10 of 1998.

24. Regulation of the Constitutional Court No. 06 / PMK / 2005 concerning the Guidelines for Procedure in the Case of Testing Law. 